\title{
Current challenges in different approaches to control COVID-19: a comprehensive review
}

Simran Giri, Sanjukta Sen, Rohan Singh, Paramita Paul, Ranabir Sahu, Gouranga Nandi and Tarun Kumar Dua* (D)

\begin{abstract}
Background: The World Health Organization declared the outbreak of the novel coronavirus (COVID-19) as a global health emergency on January 30,2020, and as a pandemic disease on March 11, 2020. This review highlights the international situation, risk factors, and related protections to be taken as prerequisite measures and probable treatment options for the COVID-19-infected population in the current scenario.

Main text: The SARS-CoV-2 viruses and their variants caused mild-to-severe respiratory tract infection and used airborne pathways as a way of contagion. Human-to-human transmission led to an exponential growth in the rise in the number of cases making it a real burden to immobilize the rapid spread of the virus while asymptomatic patients created ambiguity for confirmation in the community. It was clear from the case studies of patients that most of them were asymptomatic but still vulnerable to the people around, and hence, in a flash, many countries around the globe went into a complete lockdown, influencing the economy and thrashing industrial outputs. On the other hand, numerous researches were made to counteract the spread through studies in antiviral therapy, immune-based therapy, vaccination development, and natural remedies.

Conclusion: Although exploration for a specific drug required for the COVID-19 treatment is under extensive research worldwide and some of them are in clinical trial now. Virtual drug library screening is one of the current techniques for repurposing accessible compounds. This review could provide beneficial information about the potential current and future treatment strategies to treat the pandemic COVID-19 infection.
\end{abstract}

Keywords: COVID-19, SARS-CoV-2, Coronavirus, Pandemic, Respiratory, Airborne, Treatment of COVID-19

\section{Background}

Severe acute respiratory syndrome coronavirus 2 (SARS$\mathrm{CoV}-2)$ is the coronavirus strain responsible for the novel coronavirus 2019 (COVID-19) infection. COVID-19 emerged in the Wuhan city of China in late 2019 and swiftly occupied many of the individuals across the city with symptoms of atypical pneumonia, resulting in an outbreak of epidemic phase (Zhu et al. 2020a, b). Later, World Health Organization (WHO) declared the outbreak as a pandemic after assessing the situation around the world on March 11, 2020 (Cucinotta and Vanelli

\footnotetext{
*Correspondence: tarunkduaju@gmail.com
}

Department of Pharmaceutical Technology, University of North Bengal, Raja Rammohunpur, P.O.- NBU, District- Darjeeling, West Bengal 734013, India
2020). By the end of July 2021, more than 192 million cases had been recorded worldwide, resulting in the deaths of more than 4.1 million individuals worldwide from the beginning of the pandemic (WHO 2022a). Evidence till now supports the statement that COVID-19 has a zoonotic source as a constructed virus would have shown genomic sequences of known elements. The other forms of coronavirus include severe acute respiratory syndrome coronavirus (SARS-CoV) and middle East respiratory syndrome coronavirus (MERS-CoV), which has severe effects on the respiratory health of humans, while human coronavirus stains such as (HCoV) HKU1, NL63, OC43, and 229E show mild symptoms (Chilamakuri and Agarwal 2021; Corman et al. 2018). Throughout the COVID-19 pandemic, SARS-CoV-2 genetic variants have emerged and spread across the world. Airborne 
transmission is a major concern of SARS-CoV-2 as the expiratory activities (i.e., coughing, sneezing) of an infected person can generate respiratory droplets and infect individuals within a radius of $6 \mathrm{ft}$ (Ghinai et al. 2020). The front portion of the mouth is where atomization of droplets occurs; thus, covering the mouth by the use of a surgical facemask is essential (Johnson et al. 2011).

The incubation period of a virus is the period between the exposure and the potential earliest date of symptoms, and current research showed that the incubation period for COVID-19 ranges from 2 to 7 days while the median estimate is 4 days (Guan et al. 2020). Fever, dry cough, dyspnea, myalgia, tiredness, regular or reduced leukocyte counts, and radiographic indications of pneumonia are all common signs of COVID-19 infection. Symptoms of lung abnormalities, lymphopenia, and thrombocytopenia have also been observed in certain COVID-19 individuals. The pathophysiological feature of COVID-19 is governed by proliferative and exudative stages of alveolar damage, necrosis of pneumocytes, inflammatory infiltrates, and microvascular damage (Carsana et al. 2020). To successfully combat current and possible future pandemics, detailed investigations of this new coronavirus, its mode of infection, and replication are required. This review focuses on the global situation, clinical manifestation, precautions to be taken as a precautionary measure, and various treatment approaches for COVID-19.

\section{Main text}

\section{History and classification}

Coronaviruses are a family of hundreds of viruses, and it was seen that the majority of these viruses showed their harmful effect on different animals like bats, chickens, camels, and cats. In the 1960s, human coronaviruses 229E and OC43 were first discovered that were able to infect humans (Andersen et al. 2020). Among human coronaviruses, four are endemic (229E, OC43, NL63, and HKU1) and are well known for causing mild diseases (Kahn and McIntosh 2005; Saxena et al. 2020).

In November 2002, the first SARS-CoV virus was identified, resulting in severe acute respiratory syndrome (SARS) (Lau et al. 2020). In 2003, the members of Canada's National Microbiology Laboratory identified this virus's genome and confirmed the reason for this outbreak (Pal et al. 2020). Since 2005, several novel coronaviruses have been recognized from bats, and the evidence showed that human respiratory coronaviruses, SARS coronavirus, and MERS coronavirus were initially derived from bat viruses ancestral (Paden et al. 2018; Burrell et al. 2017).

Another deadlier coronavirus MERS-CoV (Middle East respiratory syndrome) was discovered in 2012. In MERS, the first case was from Saudi Arabia. Later another two MERS outbreak was identified in 2015 and 2018 in South Korea and Saudi Arabia, respectively. Then the first SARS-CoV-2 or COVID-19 infection was reported in December 2019 in Wuhan city of China. The virus was first discovered in bats and then pangolins (Panyod et al. 2020; Zhang et al. 2020). The genomic structure of virus SARS-CoV and SARS-CoV-2 bears many common characteristics and shows almost similar symptoms. This disease turns life-threatening if people are suffering from SARS. A total of 774 people was died from 2002 to 2014, according to the last reported case (Abdul-Fattah et al. 2021).

On account of their genus, there are four main subgroups of coronaviruses, known as alpha $(\alpha)$, beta $(\beta)$, gamma $(\gamma)$, and delta $(\delta)$ coronaviruses. Among them $\alpha$ and $\beta$ coronaviruses are known to infect mammals, and other two $\gamma$ and $\delta$ coronaviruses are known to create infection on birds (Wertheim et al. 2013; Guo et al. 2020).

\section{Structure}

Coronaviruses are large, roughly spherical, and consisting of particles with bulbous surface projections (Goldsmith et al. 2004). It is a single-stranded RNA-enveloped virus with the largest genomes (26.4-31.7 kb) among all known RNA viruses belonging to the Coronaviridae family. The virus envelope appears to be two separate electron-dense shells in electron micrographs (Huang et al. 2020; Mousavizadeh and Ghasemi 2020; Fehr and Perlman 2015).

The viral envelope of coronaviruses consists of three main structural proteins. These are the very large glycoprotein $S$ (for spike), glycoprotein $M$ (membrane protein), and the internal phosphorylated nucleocapsid protein $(\mathrm{N})$, and there is another minor transmembrane protein E also present (Fig. 1) (Burrell et al. 2017; Huang et al. 2020). Each type of protein in the virions of coronaviruses shows different characteristics

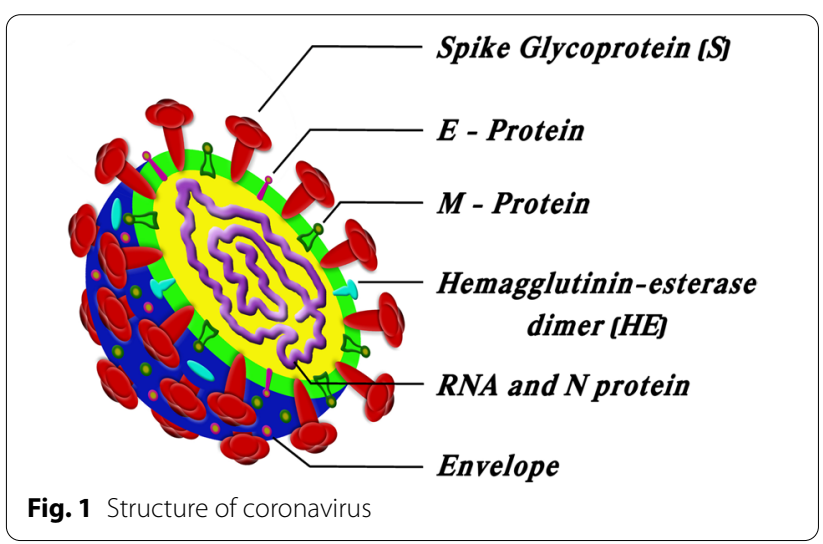


Table 1 Characteristics of different types of structural protein (Haque et al. 2020; Huang et al. 2020; Boopathi et al. 2021; Mousavizadeh and Ghasemi 2020)

\begin{tabular}{ll}
\hline Type of structural protein & Characteristics \\
\hline Nucleocapsid protein (N) & $\begin{array}{l}\text { N-protein coats the viral RNA genome which plays a vital role in its replication and transcription. It is responsible for } \\
\text { encapsulating and protecting (+)-RNA, which contains the virus genome }\end{array}$ \\
Spike protein (S) & $\begin{array}{l}\text { Type I membrane glycoprotein is made of 1160-1400 amino acids } \\
\text { S-protein facilitates viral entrance into the host cell by mediating receptor-binding and membrane fusion between the } \\
\text { virus and the host cell } \\
\text { E-protein is a tiny membrane protein with 76-109 amino acids that is a minor component of the viral particle. It is } \\
\text { involved in virus assembly, host cell membrane permeability, and virus-host cell contact } \\
\text { The M-protein is most prevalent on the viral surface and is thought to be the coronavirus's major organizer. It neutralizes } \\
\text { the virus-specific antibodies that have formed inside the host cell } \\
\text { Determines the shape of the viral envelope } \\
\text { The HE protein may have a role in viral entrance; it is not necessary for virus replication, but it appears to be important for } \\
\text { natural host cell infection }\end{array}$
\end{tabular}

(Table 1). Moreover, some coronaviruses further contain a shorter spikelike surface protein termed hemagglutinin esterase (HE) (Haque et al. 2020). The surface spikes of coronavirus are homotrimers of the protein $\mathrm{S}$. It comprises two subunits $\mathrm{S} 1$ and $\mathrm{S} 2$, which are associated with cell recognition and the combination of viral and cellular membranes, respectively (Coutard et al. 2020). The S1 subunit takes place at the head of the spike, and there is a receptor-binding domain (RBD). The $\mathrm{S} 2$ subunit creates a stem that attaches to the viral envelope's spike (Huang et al. 2020). The nucleocapsid (N) protein is linked to positive-sense single-stranded RNA in a continuous beads-on-a-string type fabric. The $M$ proteins and nucleocapsid protect the virus skeleton when placed outside the host cell, which is responsible for the shape of the virion (Mousavizadeh and Ghasemi 2020; Agrahari et al. 2021).

\section{SARS-CoV-2 variants}

SARS-CoV-2 is susceptible to genetic evolution, causing several variants with different features than their ancestral strains. Several variations of SARS-CoV-2 have been reported throughout this pandemic, of which only a handful are considered variants of concern (VOCs) by the WHO, considering their propensity to produce greater transmissibility or virulence, reduction in neutralization by antibodies obtained via natural infection or vaccination, the capacity to avoid detection, or a decline in treatments or vaccine efficacy (Cascella et al. 2022; WHO 2022b). Variants having particular genetic markers that have been linked to alterations are known as variants of interest (VOIs). The Centers for Disease Control and Prevention (CDC) and WHO have developed a categorization method for separating SARS-CoV-2 variations into VOCs and VOIs. An updated list (Table 2) of VOCs and VOIs has been prepared by WHO to assist in establishing monitoring and research priorities (WHO 2022b).

\section{Global situation}

COVID-19 confirmed cases were increased within a few months from its emergence, then by the mid of February 2021, confirmed cases were reduced to some extent, and in April and August 2021, confirmed cases have increased. In January 2022, confirmed cases increased enormously. As per the WHO report, by January 25, 2022, there have been $364,191,494$ confirmed cases of COVID-19, including 5,631,457 deaths. According to the WHO report, the world's confirmed cases and mortality with time during this pandemic has been explained with a graphical presentation in Fig. 2 (WHO 2022a).

\section{Clinical manifestations}

COVID-19 is a contiguous disease and is transmittable from an infected person to healthy individuals via air droplets, and the virus can affect different people in peculiar ways. Mild-to-moderate illness occurs in the infected people, while some recover without prior hospitalization. The most prevalent symptoms of COVID-19 patients are fever, muscular or body pains, dry cough, loss of taste or smell, myalgia or tiredness, pneumonia, and complex dyspnea, and less common symptoms are designated by aches and pains, sore throat, diarrhea, conjunctivitis, headache, skin rash, discolouration of fingers or toes, nausea, and vomiting. Breathing difficulties, shortness of breath, chest discomfort or pressure, and loss of speech or movement are all severe symptoms. Different symptoms of COVID-19 patients have been graphically represented in Fig. 3. Most symptoms appear 2-14 days after virus exposure in most symptomatic patients (Huang et al. 2020). For patients with health comorbidities, such 
Table 2 List of SARS-CoV-2 variants of concern (VOCs) and variants of interest (VOls) (Cascella et al. 2022; WHO 2022b)

\begin{tabular}{llll}
\hline Name of the variant & Lineage & First reported & Date of the first report \\
\hline $\begin{array}{lll}\text { Variants of concern (VOCs) } \\
\text { Alpha }\end{array}$ & UK, September 2020 & December 18, 2020 \\
Beta & B.1.1.7 & South Africa, May 2020 & December 18, 2020 \\
Gamma & B.1.351 & Brazil, November 2020 & January 11, 2021 \\
Delta & P.1 & India, October 2020 & VOl: April 4, 2021 VOC: May 11, \\
& B.1.617.2 & & 2021 \\
Omicron & S.1.1.529 & South Africa, November 2021 & November 26, 2021 \\
Variants of interest (VOIs) & & & March 5, 2021 \\
Epsilon & B.1.427/B.1.429 & USA, March 2020 & March 17, 2021 \\
Zeta & P.2 & Brazil, April 2020 & March 17, 2021 \\
Eta & B.1.525 & Multiple countries, December 2020 & March 24, 2021 \\
Theta & P.3 & Philippines, January 2021 & March 24, 2021 \\
lota & B.1.526 & USA, November 2020 & April 4, 2021 \\
Kappa & B.1.617.1 & India, October 2020 & June 14, 2021 \\
Lambda & C.37 & Peru, August 2020 & August 30, 2021 \\
Mu & B.1.621 & Colombia, January 2021 &
\end{tabular}

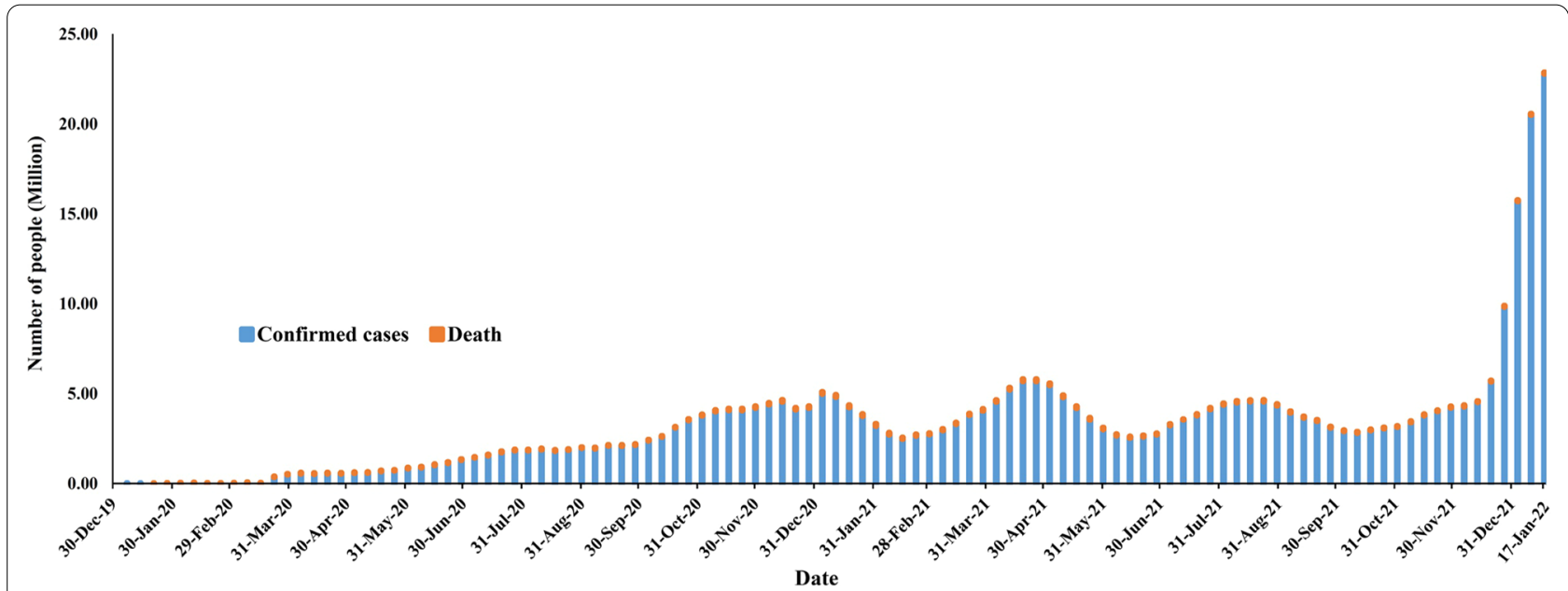

Fig. 2 Total number of confirmed cases and deaths globally at the end of every week from its emergence

as cardiovascular illnesses, renal impairment, liver dysfunction, diabetes, Parkinson's disease, and cancer, both young and old individuals' health might get complicated. Most people with mild-to-moderate illness may recover without requiring special treatment. Within 2-4 weeks of therapy, healthy people may recover from the viral illness (Harcourt et al. 2020).

\section{Preventions}

Prevention is better than cure; hence, the spread of this disease can be controlled by paying constant attention to some basic preventative measures (Fig. 4) given below.
- Get vaccine on time, and follow the local vaccination guideline.

- Maintain social distancing of at least 1-m space between yourself and others to reduce your threat of infection when others cough, sneeze, or talk (Huang et al. 2021).

- Use a face mask when being around other people (Clapham and Cook 2021).

- Frequently, in a proper manner, clean and rub your hands (at least $20 \mathrm{~s}$.) with an alcohol-based hand wash or usage soap, followed by rinsing with water. If hand wash or soap is not available, use alcohol-based hand sanitizer (minimum 60\% alcohol). 


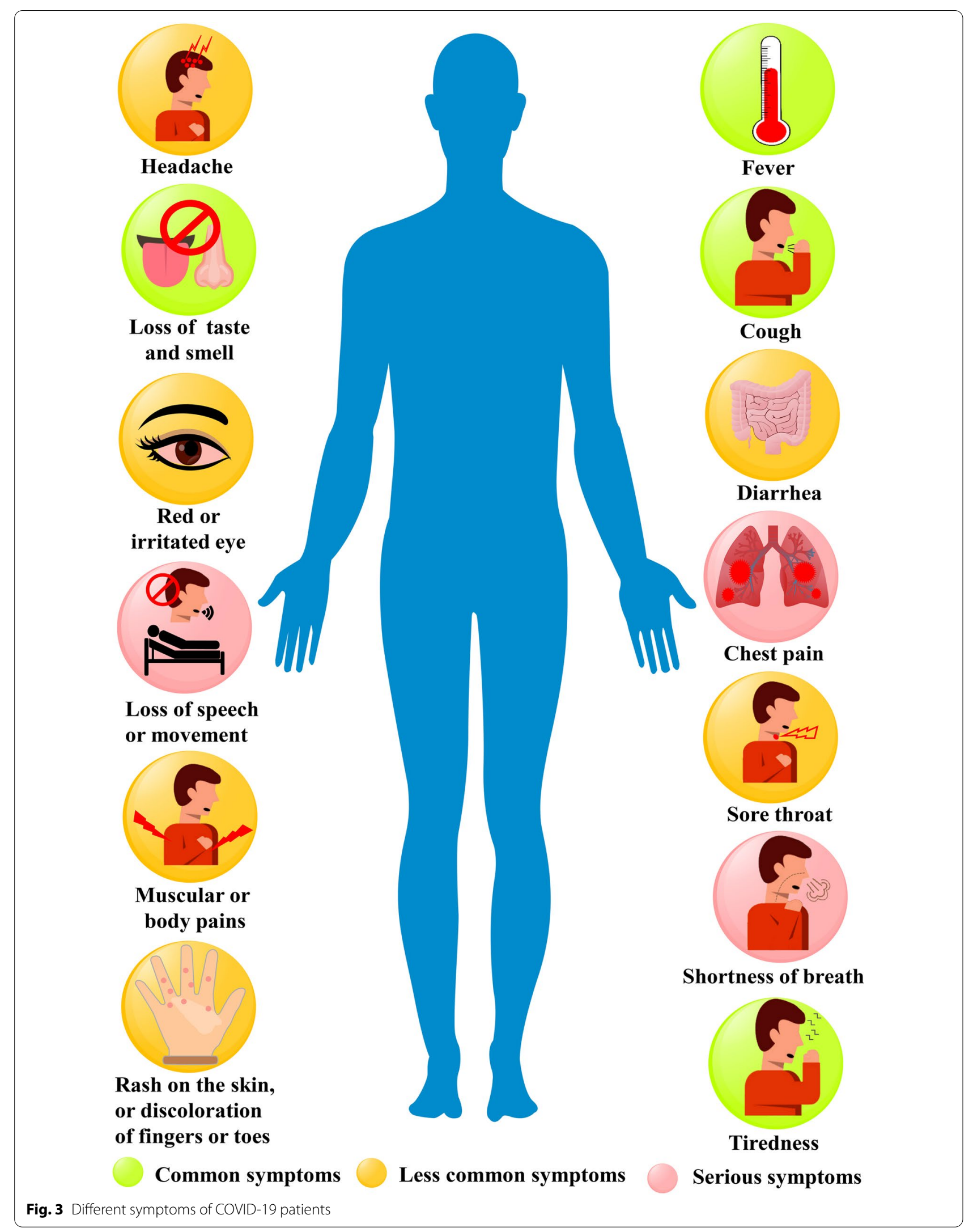




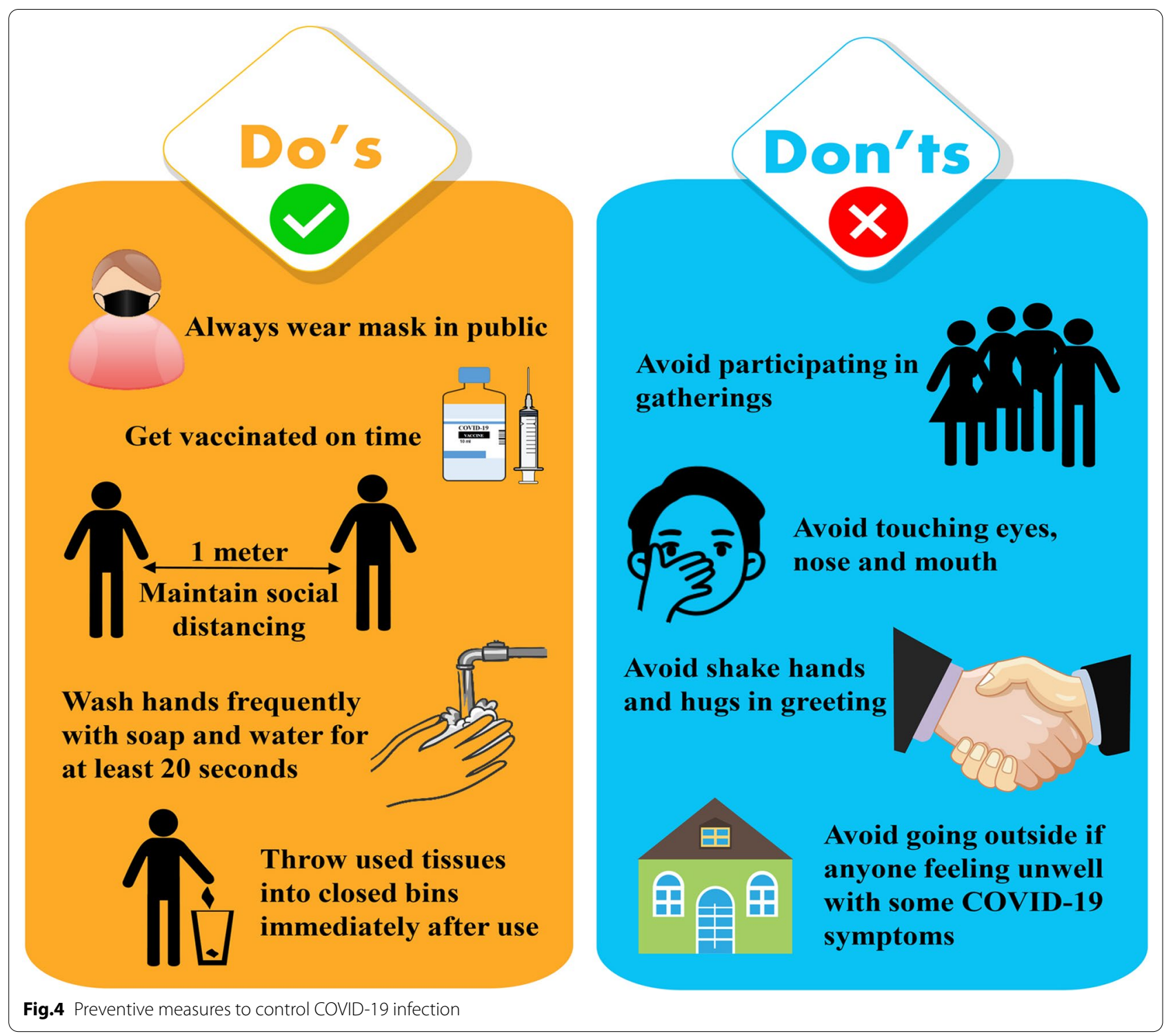

- Avoid going to crowded, congested, and/or involving close touch areas.

- Surfaces that are often handled, such as doorknobs, faucets, and phone displays, should be cleaned and disinfected regularly.

- Cover the nose and the mouth with the bent elbow or tissue during coughing or sneezing. After that, throw away the used tissue in a closed container and wash hands to maintain good respiratory hygiene.

- If anyone is feeling unwell with some COVID-19 mild symptoms, they should stay home and self-isolate until they recover. If the person develops fever, cough, or difficulty breathing, get medical treatment, call the doctor ahead of time if possible, and follow your local health authority's instructions (WHO 2022c).

\section{Present treatments of COVID-19}

Since the beginning of the COVID-19 pandemic, different measures have been taken to treat COVID-19 infection. Still, there is no clinically validated and specific antiviral medication available to treat COVID-19 infection at this time. Patients are usually provided medical treatment or supportive therapy, such as oxygen supplementation and mechanical ventilation, to alleviate symptoms (Cucinotta and Vanelli 2020). For the treatment of COVID-19 infection, many strategies have been explored, and repurposing drugs is one of them. Some of the antivirals that have been repurposed include remdisivir, lopivir, lopinavir-ritonavir, ribavirin, baloxavirmarboxil, favipiravir, and arbidol/ umifenovir. Other drugs that show potential action 
against COVID-19 but are not antivirals include chloroquine, hydroxychloroquine, corticosteroids, losartan, statins, interferons, nitric oxide, and epoprostenol, which are instances for the repurposing strategy. Some medications have been suggested for treatment in critically sick patients. Tocilizumab, siltuximab, sarilumab, anakinra, and ruxolitinib were used to treat COVID-19 individuals who developed cytokine release syndrome (CRS). Antibiotics like azithromycin are frequently used to treat secondary infections (Ginsburg and Klugman 2020). The vaccine is another better approach for the prevention of COVID-19 infection. Though various vaccines against the SARS-CoV-2 virus have recently been approved, availability remains a major barrier, and public acceptance has become a contentious issue. But day by day, SARS-CoV-2 virus becomes more contagious and harmful due to their new mutants called variants. Recently the omicron variant's capacity to evade vaccine-elicited immunity is a major concern. So, there is a requirement for potential therapeutic molecules to treat the infection. Several antiviral drugs might be potentially repurposed or developed into viable treatments for this novel coronavirus. However, several clinical trials exploring possible therapies are now underway.

\section{Remdesivir}

Remdesivir is a broad-spectrum antiviral drug with antiviral efficacy in vitro against SARS-CoV-2 by inhibiting viral replication (Wang et al. 2020). According to Holshue et al. (2020), the first instance in the USA (reported in Washington State) was treated with an intravenous injection of remdesivir, which alleviated symptoms and had no adverse effects. In randomized controlled clinical studies, remdesivir was shown to be superior to placebo in decreasing the time to recovery in patients hospitalized with mild-to-severe COVID-19 infection (Beigel et al. 2020; Goldman et al. 2020). Remdesivir was approved by US Food and Drug Administration on October 22, 2020, for the treatment of COVID-19 necessitating hospitalization in adult and children patients 12 years old and weighing a minimum of $40 \mathrm{~kg}$ (US FDA 2021).

\section{Favipiravir}

Favipiravir is a broad-spectrum antiviral and antiinfluenza drug that restricts viral RNA replication by inhibition of RNA polymerase (Fang et al. 2020). Several studies have revealed that favipiravir can effectively treat COVID-19, particularly in patients with mild-tomoderate disease. Favipiravir has been demonstrated in certain investigations to lower viral load in the upper respiratory tract and the lungs (Shirali and Daikoku 2020).
Additional well-designed trials, including therapy dosage and duration investigations, are required before conclusive findings can be reached (Manabe et al. 2021).

\section{Lopinavir-Ritonavir}

It is an FDA-approved antiretroviral medication for HIV disease that was recommended as an antiviral treatment for COVID-19 during the early stages of the pandemic. A randomized control study in individuals hospitalized with severe COVID-19 found no benefit from lopinavirritonavir therapy compared to the standard of care (Cao et al. 2020).

\section{Arbidol}

Arbidol is also known as umifenovir, a Russian antiviral drug that seems to be effective against many viruses, including influenza, respiratory syncytial virus (RSV), poliovirus, rhinovirus, Zika virus, hepatitis and SARS$\mathrm{CoV}$, and MERS-CoV coronaviruses (Gao et al. 2020). The trimerization of SARS-CoV-2 spike glycoprotein, which is important for cell adhesion and penetration, may be effectively blocked or hampered by arbidol. When the trimerization of the SARS-CoV-2 spike glycoprotein is blocked, a bare or immature virus is formed, which is less infectious (Vankadari 2020). As a host-targeting drug, Arbidol also disrupts many steps of viral cycle replication, including entrance, attachment, internalization, and membrane fusion. Arbidol substantially improved the clinical state of hospitalized COVID-19 patients, including peripheral oxygen saturation, the need for ICU admissions, the length of hospitalization, chest computed tomography involvements, white blood cells, and erythrocyte sedimentation rate, according to a randomized controlled trial (Nojomi et al. 2020).

\section{Ivermectin}

Ivermectin is a broad-spectrum antiparasitic drug that the FDA has authorized. Based on an in vitro research that indicated the reduction of SARS-CoV-2 replication, it was utilized globally to treat COVID-19. Later on, a randomized control study including 476 adult patients with moderate COVID-19 disease could not produce substantial improvement or remission of symptoms after being randomized to take ivermectin for 5 days or a placebo (Caly et al. 2020).

\section{Chloroquine and hydroxychloroquine}

Chloroquine and hydroxychloroquine have a long history of use in the inhibition and treatment of malaria and the treatment of chronic inflammatory disorders such as rheumatoid arthritis. Hydroxychloroquine is derived from chloroquine, and initially, they have been 
proposed as an antiviral treatment for COVID-19 (Gasmi et al. 2021; Horby et al. 2020). Later on, a randomized controlled trial reported that hydroxychloroquine was administered as a postexposure prophylactic within 4 days of a high-risk or moderate-risk COVID-19 exposure, and hydroxychloroquine did not protect against COVID-19-related illness or infection (Boulware et al. 2020; Mitjà et al. 2021). Another open-label randomized controlled trial reported that chloroquine/hydroxychloroquine treatment in patients brought to the hospital with severe COVID-19 resulted in clinical deterioration and increased rates of invasive mechanical ventilation and renal failure (Réa-Neto et al. 2021). The Food and Drug Administration (FDA) granted emergency use authorization (EUA) to chloroquine and hydroxychloroquine in May 2020 to treat severe cases of COVID-19 in hospital settings. The FDA, however, removed the emergency use authorization for chloroquine and hydroxychloroquine on June 15,2020 , in situations where clinical studies were lacking (Omokhua-Uyi and Staden 2021).

\section{Anakinra}

Anakinra is a $17-\mathrm{kD}$ recombinant human IL-1 receptor antagonist (blocking both IL- $1 \alpha$ and IL-1 $\beta$ ), with a short half-life of around 3-4 $\mathrm{h}$ and a favorable safety profile, authorized for the treatment of rheumatoid arthritis, gouty arthritis, and other uncommon auto-inflammatory disorders. Anakinra is a safe and effective treatment strategy for delaying mechanical ventilation, reducing the need for supplemental oxygen, and regulating SARS$\mathrm{CoV}$-2-triggered inflammation in patients with severe COVID-19 pneumonia and a high oxygen need (Balkhair et al. 2021). Later on, Tharaux et al. reported that the patients with COVID-19 and mild-to-moderate pneumonia, a randomized clinical study found that anakinra was ineffective in lowering the requirement for noninvasive or mechanical ventilation or mortality. More research is needed to determine the effectiveness of anakinra in additional categories of individuals with more severe COVID-19 and in different settings (Tharaux et al. 2021).

\section{Tocilizumab}

Tocilizumab, a monoclonal anti-interleukin-6 (IL-6) antibody, has been identified as a possible therapeutic option for COVID-19 patients at risk of cytokine storms. IL-6 is an essential cytokine in inflammatory reaction and immune response and is one of the most significant cytokines involved in COVID-19-induced cytokine storms (Luo et al. 2020). However, a different study report showed that it is an effective treatment preference for critically ill COVID-19 patients, as it substantially reduces their oxygen requirements and their ICU stay, median hospital stay, and death. COVID-19-induced cytokine storms are effectively treated with this drug by decreasing the level of IL-6 (Chachar et al. 2021; Luo et al. 2020).

\section{Sotrovimab}

Sotrovimab, a monoclonal antibody, has been developed to treat various types of coronaviruses, including COVID-19. It is primarily used to treat mild and moderate COVID-19 infection and prevent the progression of the disease condition from critical to severe. A retrospective study reported that the use of sotrovimab significantly improved symptom resolution, outcome, laboratory marker, and decreased hospitalization rate in individuals with mild and moderate COVID-19. This study suggests the use of sotrovimab in the early stages of COVID-19 treatment (Elesdoudy 2021). Later on, Guta and his group reported that the sotrovimab lowered the probability of disease progression in high-risk patients with mild-to-moderate COVID-19. And there were no threatening signs found during the study (Gupta et al. 2021). The use of sotrovimab for treating mild or moderate COVID-19 in patients at high risk of hospitalization has also been conditionally recommended by the WHO (Kmietowicz 2022).

\section{Dexamethasone}

Dexamethasone is a glucocorticoid drug used to treat COVID-19 infection. In hospitalized patients with COVID-19 and respiratory failure who needed supplementary oxygen or mechanical ventilation, a low dose of dexamethasone (6 $\mathrm{mg}$ daily for 10 days) reduced death. Data also suggest that mortality may be higher in hospitalized patients who do not receive oxygen (Matthay and Thompson 2020).

\section{Ruxolitinib}

Ruxolitinib is an inhibitor of JAK 1 and 2 used to treat myelofibrosis (Wang et al. 2020). JAK inhibitors reduced the need for invasive mechanical ventilation and improved survival in people with COVID-19, most significantly baricitinib (Chen et al. 2021). Ruxolitinib, a JAK inhibitor, is under phase III clinical trial of patients with COVID-19 associated with cytokine storm and acute respiratory disorder syndrome (Valenzuela-Almada et al. 2021).

\section{Baricitinib}

Baricitinib is a Janus kinase (JAK) 1 and 2 inhibitor used to treat rheumatoid arthritis (Cantini et al. 2020). One of the most usually prescribed medicines for COVID-19-related pneumonia is baricitinib. WHO also recommends it for the treatment of COVID-19 (Kmietowicz 2022). It is a well-known medication with a strong affinity for infected 
cells (Richardson et al. 2020). According to statistics, creatine kinase in patients who took bacitracin surpassed the allowed threshold. Alternatively, high creatine kinase levels might make it difficult to start baricitinib therapy (Praveen et al. 2020). A randomized, double-blind, placebo-controlled study found that combining the baricitinib with remdesivir to treat hospitalized patients with COVID-19 pneumonia was safe and preferable to remdesivir alone. The confluence was associated with a lower risk of severe side effects (Kalil et al. 2021).

\section{Convalescent plasma therapy}

Convalescent plasma treatment is a type of adoptive immunotherapy that can treat a wide range of illnesses. Passive immunity can be created by using antiviral antibodies from recovered individuals to treat additional patients with a specific infectious illness. Other respiratory viral diseases, including SARS-CoV-1, H1N1 influenza, MERS-CoV, West Nile virus, and Ebola virus, have recently been treated with this technique (Marano et al. 2016). Hyperimmune immunoglobulin showed a statistically significant reduction in the risk of death among those treated with convalescent plasma or serum in all of the investigations (Al-Tawfiq and Arabi 2020). This treatment has played an essential role in treating COVID-19 patients when no effective antiviral drugs are available. In an initial uncontrolled case series, five critically sick patients with COVID-19 and acute respiratory distress syndrome underwent convalescent plasma treatment, and the result showed improvement in their clinical status (Shen et al. 2020). Later on, Duan et al. (2020) reported that a single dosage of CP $(200 \mathrm{~mL})$ was well tolerated and could considerably raise or sustain neutralizing antibodies at a high level, resulting in viremia disappearing in 7 days. However, clinical symptoms improved quickly over 3 days. This suggests that $\mathrm{CP}$ might be a viable rescue strategy for severe COVID-19 and that a randomized study is necessary. Due to sample and experimental design constraints, a definitive conclusion on the potential efficacy of this form of treatment cannot be made, and further clinical observations will be required.

\section{Azithromycin}

Antibiotic azithromycin belongs to the macrolide family used to treat a wide range of Gram-positive bacterial infections. By interfering with protein synthesis and mRNA translation, it inhibits bacterial growth. This antibiotic is useful in the treatment of bacterial pneumonia. In addition to its antibacterial properties, it possesses immunomodulatory and anti-inflammatory properties, which may help to reduce the difficulties caused by respiratory viral infections such as COVID-19 (Pani et al. 2020; Echeverría-Esnal et al. 2021; Oldenburg and
Doan 2020). However, according to the meta-analysis study by Mangkuliguna et al. (2021), in COVID-19 patients, azithromycin did not provide significant clinical improvement, although it was well tolerated and safe to use. Because of the absence of therapeutic advantages, azithromycin should be avoided to use routinely unless bacterial pneumonia is present. So, further clinical studies are required to elucidate the role of azithromycin in COVID-19 treatment.

\section{Vaccines}

The world has taken different significant actions to control the COVID-19 pandemic from its beginning. However, the disease spreads unabated, wreaking havoc on people's health, social lives, and economies. Therefore, the prevention and control of the COVID-19 pandemic were immediately needed. Several vaccines have been studied, produced, tested, and assessed at a breakneck speed, and in 2021 many vaccines have been approved. According to the $\mathrm{WHO}$, more than 9.8 billion vaccination doses had been delivered as of January 27, 2022 (WHO 2022a). The immune system is triggered by vaccination, resulting in the generation of neutralizing antibodies against SARS-CoV-2. But the variants of the virus are always a major cause of concern. Vaccines have long been known to lose their potency over time. As a result, various countries have authorized the administration of an additional dose of vaccine (known as a booster) to people 3-5 months after their vaccination cycle is completed. This method appears to be efficient in preserving SARS-CoV-2 immunity. Some important vaccines of the world are listed in Table 3.

\section{Conclusions}

Extensive research has been being carried out on SARS$\mathrm{CoV}-2$ and its different variants to combat them with the new treatment strategies. With the continued enormously hard efforts to prevent the spread of SARSCoV- 2 globally, we hope that this pandemic disease will subside in the coming couple of months like SARS and MERS. Some strategies like vaccination, social distancing, self-quarantine, stay home, stay safe, night curfew, partial or complete lockdown, maintaining hygiene, wearing masks, and using hand sanitizer frequently have been imposed to control the transmission of COVID-19. Moreover, parallel clinical trials have been conducted on the proposed therapeutic options, including vaccines and potent drugs repurposed for COVID. The global availability of COVID-19 vaccines has been compensated for and overcome by international collaborations and competitions among pharmaceutical industries and researchers in scientific institutions, starting with the historically fast clinical trials. To produce safe and effective vaccines, 
Table 3 Some approved COVID-19 vaccines with their developer, origin, type, dosage and storage conditions

\begin{tabular}{|c|c|c|c|c|c|c|c|}
\hline $\begin{array}{l}\text { Name of the } \\
\text { vaccine }\end{array}$ & Developer & Developer country & Vaccine type & No. of doses & Efficacy (\%) & Storage $\left({ }^{\circ} \mathrm{C}\right)$ & References \\
\hline $\begin{array}{l}\text { BNT162b2 (Comir- } \\
\text { naty) }\end{array}$ & Pfizer-BioNtech & USA and Germany & mRNA & $\mathrm{IM}(2)$ & 95 & -80 to -60 & Polack et al. (2020) \\
\hline $\begin{array}{l}\text { mRNA-1273 } \\
\text { (Moderna COVID-19 } \\
\text { Vaccine) }\end{array}$ & Moderna & USA & mRNA & $\mathrm{IM}(2)$ & 94.0 & -25 to -15 & Baden et al. (2021) \\
\hline $\begin{array}{l}\text { Ad26.COV2.S } \\
\text { (Janssen COVID-19 } \\
\text { vaccine) }\end{array}$ & $\begin{array}{l}\text { Janssen Pharmaceu- } \\
\text { ticals }\end{array}$ & USA and Germany & Viral vector & $\mid \mathrm{M} 1$ & 81.7 & $2-8$ & Sadoff et al. (2021) \\
\hline $\begin{array}{l}\text { ChAdOx1 nCoV-19 } \\
\text { (AZD-1222) (Cov- } \\
\text { ishield) }\end{array}$ & Oxford-AstraZeneca & $\begin{array}{l}\text { UK, Sweden and } \\
\text { India }\end{array}$ & Viral vector & $\mathrm{IM}(2)$ & 81 & $2-8$ & Voysey et al. (2021) \\
\hline SputnikV & $\begin{array}{l}\text { Gamaleya Research } \\
\text { Institute }\end{array}$ & Russia & Viral vector & $\mathrm{IM}(2)$ & 91.6 & $2-8$ & Logunov et al. (2021) \\
\hline BBV152 (Covaxin) & Bharat Biotech & India & Inactivated & $\mathrm{IM}(2)$ & 78 & $2-8$ & Ella et al. (2021) \\
\hline CronaVac & Sinovac & China & Inactivated & $\mathrm{IM}(2)$ & 50.4 & $2-8$ & Zhang et al. (2021) \\
\hline BBIBP-CorV & Sinopharm & China & Inactivated & $\mathrm{IM}(2)$ & 79.3 & $2-8$ & Xia et al. (2021) \\
\hline NVX-CoV2373 & Novavax & USA & Protein subunit & $\mathrm{IM}(2)$ & 96 & $2-8$ & Shinde et al. (2021) \\
\hline CVnCoV & Curevac & Germany & mRNA & $\mathrm{IM}(2)$ & 48.2 & $2-8$ & Hadj Hassine (2021) \\
\hline $\begin{array}{l}\text { AD5-nCOV (Con- } \\
\text { videcia) }\end{array}$ & CanSino Biologics & China & Viral vector & $\mid \mathrm{M}, \mathrm{IN}(1)$ & 63 & $2-8$ & Wu et al. (2021) \\
\hline SCB-2019 & $\begin{array}{l}\text { Clover Biopharma- } \\
\text { ceu ticals }\end{array}$ & China & Protein subunit & $\mathrm{IM}$ & 67 & $2-8$ & Bravo et al. (2022) \\
\hline ZyCoV-D & Cadila Healthcare & India & DNA plasmid & ID (3) & 66.6 & $2-8$ & Chavda et al. (2021) \\
\hline ZF2001 (Zifivax) & $\begin{array}{l}\text { Anhui Zhifei Long- } \\
\text { com }\end{array}$ & China & Protein subunit & $\mathrm{IM}(3)$ & 82 & $2-8$ & Yang et al. (2021) \\
\hline
\end{tabular}

IM intramuscular, IN intranasal, ID intradermal

various technologies have been used. Presently, multiple vaccines have been approved, which are significantly efficacious toward prevention of COVID-19. Some of them are also showing promising results against newer strains. This review would help the readers to understand the current scenario of the COVID-19 pandemic.

\section{Future prospective}

The pandemic situation by SARS-CoV-2 is still wreaking havoc all over the world due to the rapid spreading ability of the virus, the lack of risk assessment, and the inclination to precipitate severe illness in co-morbid conditions. The associated enhancement in the mortality rate is genuinely an alarming public health issue. Disease control has become more complex with the increasing number of COVID-19 cases per day, particularly because no effective drugs against COVID-19 are being identified. In the current review, we presented a brief overview of SARS$\mathrm{CoV}-2$ infection ongoing treatment options based on the significant recent findings on some therapeutic strategies that could be used for future treatment of SARS-CoV-2 infection. Nonetheless, additional advanced research in the area and clinical studies would reveal the significance of the findings of the current review.

\begin{abstract}
Abbreviations
WHO: World Health Organization; COVID-19: Novel coronavirus; US FDA: US Food and Drug Administration; SARS-CoV-2: Severe acute respiratory syndrome coronavirus 2; SARS-CoV: Severe acute respiratory syndrome coronavirus; SARS: Severe acute respiratory syndrome; MERS: Middle East respiratory syndrome; HE: Hemagglutinin esterase; RBD: Receptor-binding domain; VOCs: Variants of concern; VOls: Variants of interest; CDC: Centers for Disease Control and Prevention; CRS: Cytokine release syndrome.
\end{abstract}

\section{Acknowledgements}

The authors sincerely acknowledge the University of North Bengal, India for providing support and facilities, and e-resources to conduct this work.

\section{Authors' contributions}

S.G. conducted literature review, extracted relevant information, prepared the tables, and reviewed and revised the manuscript; S.S. conducted literature review, extracted relevant information, drafted a part of the manuscript, and reviewed; R.S. conducted literature review, extracted relevant information, and drafted a part of the manuscript; P.P. compiled the data and critically reviewed the manuscript, prepared figures, and revised the manuscript; G.N. and R.S. critically reviewed the manuscript for important intellectual content; T.K.D. conceived and designed the study, critically reviewed the manuscript for important intellectual content, and revised the manuscript. All authors read and approved the final manuscript.

\section{Funding}

Not applicable.

\section{Availability of data and materials} Not applicable. 


\section{Declarations}

Ethics approval and consent to participate

Not applicable.

\section{Consent for publication}

Not applicable.

\section{Competing interests}

The authors declare that they have no competing interests.

Received: 5 September 2021 Accepted: 13 February 2022

Published online: 03 March 2022

\section{References}

Abdul-Fattah S, Pal A, Kaka N, Kakodkar P (2021) History and recent advances in coronavirus discovery. In: Roy K (ed) In silico modeling of drugs against coronaviruses. Methods in pharmacology and toxicology. Humana, New York. https://doi.org/10.1007/7653_2020_47

Agrahari R, Mohanty S, Vishwakarma K, Nayak SK, Samantaray D, Mohapatra S (2021) Update vision on COVID-19: structure, immune pathogenesis, treatment and safety assessment. Sens Int 2:100073. https://doi.org/10. 1016/j.sintl.2020.100073

Al-Tawfiq JA, Arabi Y (2020) Convalescent plasma therapy for coronavirus infection: experience from MERS and application in COVID-19. Hum Vaccines Immunother 16(12):2973-2979. https://doi.org/10.1080/21645515 2020.1793712

Andersen KG, Rambaut A, Lipkin WI, Holmes EC, Garry RF (2020) The proximal origin of SARS-CoV-2. Nat Med 26(4):450-452. https://doi.org/10.1038/ s41591-020-0820-9

Baden LR, El Sahly HM, Essink B, Kotloff K, Frey S, Novak R, Diemert D, Spector SA, Rouphael N, Creech CB, McGettigan J (2021) Efficacy and safety of the mRNA-1273 SARS-CoV-2 vaccine. N Engl J Med 384(5):403-416. https:// doi.org/10.1056/nejmoa2035389

Balkhair A, Al-Zakwani I, Al Busaidi M, Al-Khirbash A, Al Mubaihsi S, BaTaher H, Al Aghbari J, Al Busaidi I, Al Kindi M, Baawain S, Al Alawi A (2021) Anakinra in hospitalized patients with severe COVID-19 pneumonia requiring oxygen therapy: results of a prospective, open-label, interventional study. Int J Infect Dis 103:288-296. https://doi.org/10.1016/j.ijid.2020.11.149

Beigel JH, Tomashek KM, Dodd LE, Mehta AK, Zingman BS, Kalil AC, Hohmann E, Chu HY, Luetkemeyer A, Kline S, Lopez de Castilla D (2020) Remdesivir for the treatment of Covid-19_final report. N Engl J Med 383(19):18131826. https://doi.org/10.1056/nejmoa2007764

Boopathi S, Poma AB, Kolandaivel P (2021) Novel 2019 coronavirus structure mechanism of action, antiviral drug promises and rule out against its treatment. J Biomol Struct Dyn 39(9):3409-3418. https://doi.org/10.1080/ 07391102.2020 .1758788

Boulware DR, Pullen MF, Bangdiwala AS, Pastick KA, Lofgren SM, Okafor EC, Skipper CP, Nascene AA, Nicol MR, Abassi M, Engen NW (2020) A randomized trial of hydroxychloroquine as postexposure prophylaxis for Covid-19. N Engl J Med 383(6):517-525. https://doi.org/10.1056/nejmo a2016638

Bravo L, Smolenov I, Han HH, Li P, Hosain R, Rockhold F, Clemens SA, Roa C Jr, Borja-Tabora C, Quinsaat A, Lopez P (2022) Efficacy of the adjuvanted subunit protein COVID-19 vaccine, SCB-2019: a phase 2 and 3 multicentre, double-blind, randomised, placebo-controlled trial. Lancet 399(10323):461-472. https://doi.org/10.1016/s0140-6736(22)00055-1

Burrell CJ, Howard CR, Murphy FA (2017) Fenner and White's medical virology, 5th edn. Academic Press, London, pp 437-446

Caly L, Druce JD, Catton MG, Jans DA, Wagstaff KM (2020) The FDA-approved drug ivermectin inhibits the replication of SARS-CoV-2 in vitro. Antiviral Res 178:104787. https://doi.org/10.1016/j.antiviral.2020.104787

Cantini F, Blandizzi C, Niccoli L, Petrone L, Goletti D (2020) Systematic review on tuberculosis risk in patients with rheumatoid arthritis receiving inhibitors of Janus Kinases. Expert Opin Drug Saf 19(7):861-872. https://doi. org/10.1080/14740338.2020.1774550

Cao B, Wang Y, Wen D, Liu W, Wang J, Fan G, Ruan L, Song B, Cai Y, Wei M, Li $X$ (2020) A trial of Lopinavir-Ritonavir in adults hospitalized with severe
Covid-19. N Engl J Med 382(19):1787-1799. https://doi.org/10.1056/ nejmoa2001282

Carsana L, Sonzogni A, Nasr A, Rossi RS, Pellegrinelli A, Zerbi P, Rech R, Colombo R, Antinori S, Corbellino M, Galli M (2020) Pulmonary postmortem findings in a series of COVID-19 cases from northern Italy: a two-centre descriptive study. Lancet Infect Dis 20(10):1135-1140. https:// doi.org/10.1016/s1473-3099(20)30434-5

Cascella M, Rajnik M, Aleem A, Dulebohn S, Di Napoli R (2022) Features, evaluation, and treatment of coronavirus (COVID-19). In: Stat Pearls. Stat Pearls Publishing. https://www.ncbi.nlm.nih.gov/books/NBK554776. Accessed 29 Jan 2022

Chachar AZ, Khan KA, lqbal J, Shahid AH, Asif M, Fatima SA, Khan AA, Younis BB (2021) "Tocilizumab-an option for patients with COVID-19 associated cytokine release syndrome: a single center experience", a retrospective study-original article. Ann Med Surg 63:102165. https://doi.org/10.1016/j. amsu.2021.02.011

Chavda VP, Hossain MK, Beladiya J, Apostolopoulos V (2021) Nucleic acid vaccines for COVID-19: a paradigm shift in the vaccine development arena. Biologics 1(3):337-356. https://doi.org/10.3390/biologics1030020

Chen CX, Wang JJ, Li H, Yuan LT, Gale RP, Liang Y (2021) JAK-inhibitors for coronavirus disease-2019 (COVID-19): a meta-analysis. Leukemia. https:// doi.org/10.1038/s41375-021-01266-6

Chilamakuri R, Agarwal S (2021) COVID-19: characteristics and therapeutics. Cells 10(2):206. https://doi.org/10.3390/cells10020206

Clapham HE, Cook AR (2021) Face masks help control transmission of COVID19. Lancet Digit Health 3(3):e136-137. https://doi.org/10.1016/s25897500(21)00003-0

Corman VM, Muth D, Niemeyer D, Drosten C (2018) Hosts and sources of endemic human coronaviruses. Adv Virus Res 100:163-188. https://doi. org/10.1016/bs.aivir.2018.01.001

Coutard B, Valle C, de Lamballerie X, Canard B, Seidah N, Decroly E (2020) The spike glycoprotein of the new coronavirus 2019-nCoV contains a furin-like cleavage site absent in CoV of the same clade. Antiviral Res 176:104742. https://doi.org/10.1016/j.antiviral.2020.104742

Cucinotta D, Vanelli M (2020) WHO declares COVID-19 a pandemic. Acta Biomed 91(1):157-160. https://doi.org/10.23750/abm.v91i1.9397

Duan K, Liu B, Li C, Zhang H, Yu T, Qu J, Zhou M, Chen L, Meng S, Hu Y, Peng C (2020) Effectiveness of convalescent plasma therapy in severe COVID-19 patients. PNAS 117(17):9490-9496. https://doi.org/10.1073/pnas.20041 68117

Echeverría-Esnal D, Martin-Ontiyuelo C, Navarrete-Rouco ME, De-Antonio Cuscó M, Ferrández O, Horcajada JP, Grau S (2021) Azithromycin in the treatment of COVID-19: a review. Expert Rev Anti Infect Ther 19(2):147163. https://doi.org/10.1080/14787210.2020.1813024

Elesdoudy A (2021) Sotrovimab: is it effective in early treatment of mild and moderate COVID-19 infections? A retrospective study. Egypt J Bronchol 15:56. https://doi.org/10.1186/s43168-021-00104-8

Ella R, Reddy S, Jogdand H, Sarangi V, Ganneru B, Prasad S, Das D, Raju D, Praturi U, Sapkal G, Yadav P (2021) Safety and immunogenicity of an inactivated SARS-CoV-2 vaccine, BBV152: interim results from a doubleblind, randomised, multicentre, phase 2 trial, and 3-month follow-up of a double-blind, randomised phase 1 trial. Lancet Infect Dis 21(7):950-961. https://doi.org/10.1016/s1473-3099(21)00070-0

Fang QQ, Huang WJ, Li XY, Cheng YH, Tan MJ, Liu J, Wei HJ, Meng Y, Wang DY (2020) Effectiveness of favipiravir (T-705) against wild-type and oseltamivir-resistant influenza B virus in mice. Virology 545:1-9. https:// doi.org/10.1016/j.virol.2020.02.005

Fehr AR, Perlman S (2015) Coronaviruses: an overview of their replication and pathogenesis. Methods Mol Biol 1282:1-23. https://doi.org/10.1007/ 978-1-4939-2438-7 1

Gao W, Chen S, Wang K, Chen R, Guo Q, Lu J, Wu X, He Y, Yan Q, Wang S, Wang $F(2020)$ Clinical features and efficacy of antiviral drug, Arbidol in 220 nonemergency COVID-19 patients from East-West-Lake Shelter Hospital in Wuhan: a retrospective case series. Virol J 17(1):162. https://doi.org/10. 1186/s12985-020-01428-5

Gasmi A, Peana M, Noor S, Lysiuk R, Menzel A, Benahmed AG, Bjørklund G (2021) Chloroquine and hydroxychloroquine in the treatment of COVID19: the never-ending story. Appl Microbiol Biotechnol 105(4):1333-1343. https://doi.org/10.1007/s00253-021-11094-4

Ghinai I, McPherson TD, Hunter JC, Kirking HL, Christiansen D, Joshi K, Rubin R, Morales-Estrada S, Black SR, Pacilli M, Fricchione MJ (2020) First known 
person-to-person transmission of severe acute respiratory syndrome coronavirus 2 (SARS-CoV-2) in the USA. The Lancet 395(10230):11371144. https://doi.org/10.1016/s0140-6736(20)30607-3

Ginsburg AS, Klugman KP (2020) COVID-19 pneumonia and the appropriate use of antibiotics. Lancet Glob Health 8(12):e1453-e1454. https://doi.org/ 10.1016/s2214-109x(20)30444-7

Goldman JD, Lye DCB, Hui DS, Marks KM, Bruno R, Montejano R, Spinner CD, Galli M, Ahn MY, Nahass RG, Chen YS (2020) Remdesivir for 5 or 10 Days in Patients with Severe Covid-19. N Engl J Med 383(19):1827-1837. https:// doi.org/10.1056/nejmoa2015301

Goldsmith CS, Tatti KM, Ksiazek TG, Rollin PE, Comer JA, Lee WW, Rota PA, Bankamp B, Bellini WJ, Zaki SR (2004) Ultrastructural characterization of SARS coronavirus. Emerg Infect Dis 10(2):320-326. https://doi.org/10. 3201/eid1002.030913

Guan WJ, Ni ZY, Hu Y, Liang WH, Ou CQ, He JX, Liu L, Shan H, Lei CL, Hui DS, Du B (2020) Clinical characteristics of coronavirus disease 2019 in China. N Engl J Med 382(18):1708-1720. https://doi.org/10.1056/NEJMoa2002032

Guo Y-R, Cao Q-D, Hong Z-S, Tan YY, Chen SD, Jin HJ, Tan KS, Wang DY, Yan $Y$ (2020) The origin, transmission and clinical therapies on coronavirus disease 2019 (COVID-19) outbreak-an update on the status. Mil Med Res 7(1):1-10. https://doi.org/10.1186/s40779-020-00240-0

Gupta A, Gonzalez-Rojas Y, Juarez E, Crespo Casal M, Moya J, Falci DR, Sarkis E, Solis J, Zheng H, Scott N, Cathcart AL (2021) Early treatment for Covid19 with SARS-CoV-2 neutralizing antibody sotrovimab. N Engl J Med 385(21):1941-1950. https://doi.org/10.1056/NEJMoa2107934

Hadj Hassine I (2021) Covid-19 vaccines and variants of concern: a review. Rev Med Virol. https://doi.org/10.1002/rmv.2313

Haque SM, Ashwaq O, Sarief A, Azad John Mohamed AK (2020) A comprehensive review about SARS-CoV-2. Future Virol 15(9):625-648. https://doi.org/ 10.2217/fvl-2020-0124

Harcourt J, Tamin A, Lu X, Kamili S, Sakthivel SK, Murray J, Queen K, Tao Y, Paden CR, Zhang J, Li Y (2020) Severe acute respiratory syndrome coronavirus 2 from patient with coronavirus disease, United States. Emerg Infect Dis 26(6):1266. https://doi.org/10.3201/eid2606.200516

Holshue ML, DeBolt C, Lindquist S, Lofy KH, Wiesman J, Bruce H, Spitters C, Ericson K, Wilkerson S, Tural A, Diaz G (2020) First case of 2019 novel coronavirus in the United States. N Engl J Med 382(10):929-936. https:// doi.org/10.1056/nejmoa2001191

Horby P, Mafham M, Linsell L et al (2020) Effect of hydroxychloroquine in hospitalized patients with Covid-19. N Engl J Med 383(21):2030-2040. https://doi.org/10.1056/nejmoa2022926

Huang Y, Yang C, Xu X-f, Xu W, Liu S-w (2020) Structural and functional properties of SARS-CoV-2 spike protein: potential antivirus drug development for COVID-19. Acta Pharmacol Sin 41(9):1141-1149. https://doi.org/10. 1038/s41401-020-0485-4

Huang B, Wang J, Cai J, Yao S, Chan PK, Tam TH, Hong YY, Ruktanonchai CW, Carioli A, Floyd JR, Ruktanonchai NW (2021) Integrated vaccination and physical distancing interventions to prevent future COVID-19 waves in Chinese cities. Nat Hum Behav 5(6):695-705. https://doi.org/10.1038/ s41562-021-01063-2

Johnson G, Morawska L, Ristovski Z, Hargreaves M, Mengersen K, Chao CY, Wan MP, Li Y, Xie X, Katoshevski D, Corbett S (2011) Modality of human expired aerosol size distributions. J Aerosol Sci 42(12):839-851. https:// doi.org/10.1016/j.jaerosci.2011.07.009

Kahn JS, McIntosh K (2005) History and recent advances in coronavirus discovery. Pediatr Infect Dis J 24(11):S223-S227. https://doi.org/10.1097/01.inf. 0000188166.17324 .60

Kalil AC, Patterson TF, Mehta AK, Omashek KM, Wolfe CR, Ghazaryan V, Marconi VC, Ruiz-Palacios GM, Hsieh L, Kline S, Tapson V (2021) Baricitinib plus Remdesivir for hospitalized adults with Covid-19. N Engl J Med 384(9):795-807. https://doi.org/10.1056/nejmoa2031994

Kmietowicz Z (2022) Covid-19: WHO recommends baricitinib and sotrovimab to treat patients. BMJ 376:097. https://doi.org/10.1136/bmj.097

Lau SKP, Luk HKH, Wong ACP, Li KS, Zhu L, He Z, Fung J, Chan TT, Fung KS, Woo PC (2020) Possible bat origin of severe acute respiratory syndrome coronavirus 2. Emerg Infect Dis 26(7):1542-1547. https://doi.org/10.3201/ eid2607.200092

Logunov DY, Dolzhikova IV, Shcheblyakov DV, Tukhvatulin Al, Zubkova OV, Dzharullaeva AS, Kovyrshina AV, Lubenets NL, Grousova DM, Erokhova AS, Botikov AG (2021) Safety and efficacy of an rAd26 and rAd5 vector-based heterologous prime-boost COVID-19 vaccine: an interim analysis of a randomised controlled phase 3 trial in Russia. Lancet 397(10275):671681. https://doi.org/10.1016/s0140-6736(21)00234-8

Luo P, Liu Y, Qiu L, Liu X, Liu D, Li J (2020) Tocilizumab treatment in COVID-19: a single center experience. J Med Virol 92(7):814-818. https://doi.org/10. 1002/jmv.25801

Manabe T, Kambayashi D, Akatsu H, Kudo K (2021) Favipiravir for the treatment of patients with COVID-19: a systematic review and meta-analysis. BMC Infect Dis 21(1):489. https://doi.org/10.1186/s12879-021-06164-x

Mangkuliguna G, Glenardi SN, Pramono LA (2021) Efficacy and safety of Azithromycin for the treatment of COVID-19: a systematic review and meta-analysis. Tuberc Respir Dis (Seoul). https://doi.org/10.4046/trd.2021. 0075

Marano G, Vaglio S, Pupella S, Facco G, Catalano L, Liumbruno GM, Grazzini G (2016) Convalescent plasma: new evidence for an old therapeutic tool? Blood Transfus 14(2):152-157. https://doi.org/10.2450/2015.0131-15

Matthay MA, Thompson BT (2020) Dexamethasone in hospitalised patients with COVID-19: addressing uncertainties. Lancet Respir Med 8(12):11701172. https://doi.org/10.1016/s2213-2600(20)30503-8

Mitjà O, Corbacho-Monné M, Ubals M, Alemany A, Suñer Navarro C, Tebé C, Tobias A, Peñafiel J, Ballana E, Pérez CA, Admella P (2021) A cluster-randomized trial of hydroxychloroquine for prevention of Covid-19. N Engl J Med 384(5):417-427. https://doi.org/10.1056/nejmoa2021801

Mousavizadeh L, Ghasemi S (2020) Genotype and phenotype of COVID-19: their roles in pathogenesis. J Microbiol Immunol Infect 54(2):159-163. https://doi.org/10.1016/j.jmii.2020.03.022

Nojomi M, Yassin Z, Keyvani H, Makiani MJ, Roham M, Laali A, Dehghan N, Navaei M, Ranjbar M (2020) Effect of Arbidol (Umifenovir) on COVID-19: a randomized controlled trial. BMC Infect Dis 20(1):954. https://doi.org/10. 1186/s12879-020-05698-w

Oldenburg CE, Doan T (2020) Azithromycin for severe COVID-19. Lancet 396(10256):936-937. https://doi.org/10.1016/S0140-6736(20)31863-8

Omokhua-Uyi AG, Van Staden J (2021) Natural product remedies for COVID-19: a focus on safety. S Afr J Bot 139:386-398. https://doi.org/10.1016/j.sajb. 2021.03.012

Paden CR, Yusof M, Al Hammadi ZM, Ueen K, Tao Y, Eltahir YM, Elsayed EA, Marzoug BA, Bensalah OK, Khalafalla Al, Al Mulla M (2018) Zoonotic origin and transmission of Middle East respiratory syndrome coronavirus in the UAE. Zoonoses Public Health 65(3):322-333. https://doi.org/10.1111/zph. 12435

Pal M, Berhanu G, Desalegn C, Kandi V (2020) Severe acute respiratory syndrome coronavirus-2 (SARS-CoV-2): an update. Cureus 12(3):e7423. https://doi.org/10.7759/cureus.7423

Pani A, Lauriola M, Romandini A, Scaglione F (2020) Macrolides and viral infections: focus on azithromycin in COVID-19 pathology. Int J Antimicrob Agents 56(2):106053. https://doi.org/10.1016/j.jjantimicag.2020.106053

Panyod S, Ho CT, Sheen LY (2020) Dietary therapy and herbal medicine for COVID-19 prevention: a review and perspective. J Tradit Complement Med 10(4):420-427. https://doi.org/10.1016/j.jtcme.2020.05.004

Polack FP, Thomas SJ, Kitchin N, Absalon J, Gurtman A, Lockhart S, Perez JL, Marc GP, Moreira ED, Zerbini C, Bailey R (2020) Safety and efficacy of the BNT162b2 mRNA Covid-19 vaccine. N Engl J Med 383(27):2603-2615. https://doi.org/10.1056/nejmoa2034577

Praveen D, Puvvada RC, Vijey Aanandhi M (2020) Janus kinase inhibitor baricitinib is not an ideal option for management of COVID-19. Int J Antimicrob Agents 55(5):105967. https://doi.org/10.1016/j.ijantimicag. 2020.105967

Réa-Neto Á, Bernardelli RS, Câmara BMD, Reese FB, Queiroga MVO, Oliveira MC (2021) An open-label randomized controlled trial evaluating the efficacy of chloroquine/hydroxychloroquine in severe COVID-19 patients. Sci Rep 11(1):9023. https://doi.org/10.1038/s41598-021-88509-9

Richardson P, Griffin I, Tucker C, Smith D, Oechsle O, Phelan A, Rawling M, Savory E, Stebbing J (2020) Baricitinib as potential treatment for 2019nCoV acute respiratory disease. Lancet 395(10223):e30-e31. https://doi. org/10.1016/s0140-6736(20)30304-4

Sadoff J, Gray G, Vandebosch A, Cárdenas V, Shukarev G, Grinsztejn B, Goepfert PA, Truyers C, Fennema H, Spiessens B, Offergeld K (2021) Safety and efficacy of single-dose Ad26.COV2.S vaccine against Covid-19. N Engl J Med 384(23):2187-2201

Saxena SK, Kumar S, Maurya VK, Sharma R, Dandu HR, Bhatt MLB (2020) Current insight into the novel coronavirus disease 2019 (COVID-19). In: 
Saxena SK (ed) Coronavirus disease 2019 (COVID-19), vol 30. Springer, Singapore, pp 1-8. https://doi.org/10.1007/978-981-15-4814-7_1

Shen C, Wang Z, Zhao F, Yang Y, Li J, Yuan J, Wang F, Li D, Yang M, Xing L, Wei J (2020) Treatment of 5 critically ill patients with COVID-19 with convalescent plasma. JAMA 323(16):1582-1589. https://doi.org/10.1001/jama. 2020.4783

Shinde V, Bhikha S, Hoosain Z, Archary M, Bhorat Q, Fairlie L, Lalloo U, Masilela MS, Moodley D, Hanley S, Fouche L (2021) Efficacy of NVX-CoV2373 Covid-19 vaccine against the B.1.351 variant. N Engl J Med 384(20):18991909. https://doi.org/10.1056/nejmoa2103055

Shiraki K, Daikoku T (2020) Favipiravir, an anti-influenza drug against lifethreatening RNA virus infections. Pharmacol Ther 209:107512. https://doi. org/10.1016/j.pharmthera.2020.107512

Tharaux P-L, Pialoux G, Pavot A, Mariette X, Hermine O, Resche-Rigon M, Porcher R, Ravaud P, Bureau S, Dougados M, Tibi A (2021) Effect of anakinra versus usual care in adults in hospital with COVID-19 and mild-tomoderate pneumonia (CORIMUNO-ANA-1): a randomised controlled trial. Lancet Respir Med 9(3):295-304. https://doi.org/10.1016/s2213-2600(20) 30556-7

US FDA (2021) Coronavirus (COVID-19) drugs. https://www.fda.gov/drugs/ emergency-preparedness-drugs/coronavirus-covid-19-drugs. Accessed 18 July 2021

Valenzuela-Almada MO, Putman MS, Duarte-García A (2021) The protective effect of rheumatic disease agents in COVID-19. Best Pract Res Clin Rheumatol 35(1):101659. https://doi.org/10.1016/j.berh.2021.101659

Vankadari N (2020) Arbidol: A potential antiviral drug for the treatment of SARS-CoV-2 by blocking trimerization of the spike glycoprotein. Int J Antimicrob Agents 56(2):105998. https://doi.org/10.1016/j.ijantimicag. 2020.105998

Voysey M, Clemens SAC, Madhi SA et al (2021) Safety and efficacy of the ChAdOx1 nCoV-19 vaccine (AZD1222) against SARS-CoV-2: an interim analysis of four randomised controlled trials in Brazil, South Africa, and the UK. Lancet 397(10269):99-111. https://doi.org/10.1016/s01406736(20)32661-1

Wang M, Cao R, Zhang L, Yang X, Liu J, Xu M, Shi Z, Hu Z, Zhong W, Xiao $G$ (2020) Remdesivir and chloroquine effectively inhibit the recently emerged novel coronavirus (2019-nCoV) in vitro. Cell Res 30(3):269-271. https://doi.org/10.1038/s41422-020-0282-0

Wertheim JO, Chu DK, Peiris JS, Kosakovsky Pond SL, Poon LL (2013) A case for the ancient origin of coronaviruses. J Virol 87(12):7039-7045. https://doi. org/10.1128/jvi.03273-12

WHO (2022a) Coronavirus (COVID-19) Dashboard. https://covid19.who.int/. Accessed 28 Jan 2022a

WHO (2022b) Tracking SARS-CoV-2 variants. https://www.who.int/en/activ ities/tracking-SARS-CoV-2-variants. Accessed 28 Jan 2022b

WHO (2022c) Coronavirus disease (COVID-19) advice for the public. https:// www.who.int/emergencies/diseases/novel-coronavirus-2019/advice-forpublic. Accessed Jan $292022 C$

Wu S, Huang J, Zhang Z, Wu J, Zhang J, Hu H, Zhu T, Zhang J, Luo L, Fan P, Wang B (2021) Safety, tolerability, and immunogenicity of an aerosolised adenovirus type-5 vector-based COVID-19 vaccine (Ad5-nCoV) in adults: preliminary report of an open-label and randomised phase 1 clinical trial. Lancet Infect Dis 21(12):1654-1664. https://doi.org/10.1016/s14733099(21)00396-0

Xia S, Zhang Y, Wang Y, Wang H, Yang Y, Gao GF, Tan W, Wu G, Xu M, Lou Z, Huang W (2021) Safety and immunogenicity of an inactivated SARSCoV-2 vaccine, BBIBP-CorV: a randomised, double-blind, placebo-controlled, phase 1/2 trial. Lancet Infect Dis 21(1):39-51. https://doi.org/10. 1016/s1473-3099(20)30831-8

Yang S, Li Y, Dai L, Wang J, He P, Li C, Fang X, Wang C, Zhao X, Huang E, Wu $C$ (2021) Safety and immunogenicity of a recombinant tandem-repeat dimeric RBD-based protein subunit vaccine (ZF2001) against COVID-19 in adults: two randomised, double-blind, placebo-controlled, phase 1 and 2 trials. Lancet Infect Dis 21(8):1107-1119. https://doi.org/10.1016/s14733099(21)00127-4

Zhang T, Wu Q, Zhang Z (2020) Probable pangolin origin of SARS-CoV-2 associated with the COVID-19 outbreak. Curr Biol 30(7):1346-1351.e1342. https://doi.org/10.1016/j.cub.2020.03.022

Zhang Y, Zeng G, Pan H, Li C, Hu Y, Chu K, Han W, Chen Z, Tang R, Yin W, Chen $X$ (2021) Safety, tolerability, and immunogenicity of an inactivated SARS-CoV-2 vaccine in healthy adults aged 18-59 years: a randomised, double-blind, placebo-controlled, phase 1/2 clinical trial. Lancet Infect Dis 21(2):181-192. https://doi.org/10.1016/s1473-3099(20)30843-4

Zhu FC, Li YH, Guan XH, Hou LH, Wang WJ, Li JX, Wu SP, Wang BS, Wang Z, Wang L, Jia SY (2020a) Safety, tolerability, and immunogenicity of a recombinant adenovirus type-5 vectored COVID-19 vaccine: a doseescalation, open-label, non-randomised, first-in-human trial. Lancet 395(10240):1845-1854. https://doi.org/10.1016/s0140-6736(20)31208-3

Zhu H, Wei L, Niu P (2020b) The novel coronavirus outbreak in Wuhan, China. Glob Health Res Policy 5:6. https://doi.org/10.1186/s41256-020-00135-6

\section{Publisher's Note}

Springer Nature remains neutral with regard to jurisdictional claims in published maps and institutional affiliations.

\section{Submit your manuscript to a SpringerOpen ${ }^{\odot}$ journal and benefit from:}

- Convenient online submission

- Rigorous peer review

- Open access: articles freely available online

- High visibility within the field

- Retaining the copyright to your article

Submit your next manuscript at $\gg$ springeropen.com 